\title{
Coronary Stenosis, Crohn's Disease and Epicardial Adipose Tissue
}

\author{
Yusuke Fukuda, Masaya Yano, Shin-ichiro Miura and Keijiro Saku
}

Key words: coronary artery disease, epicardial adipose, Crohn's disease

(Intern Med 51: 329, 2012)

(DOI: 10.2169/internalmedicine.51.6534)

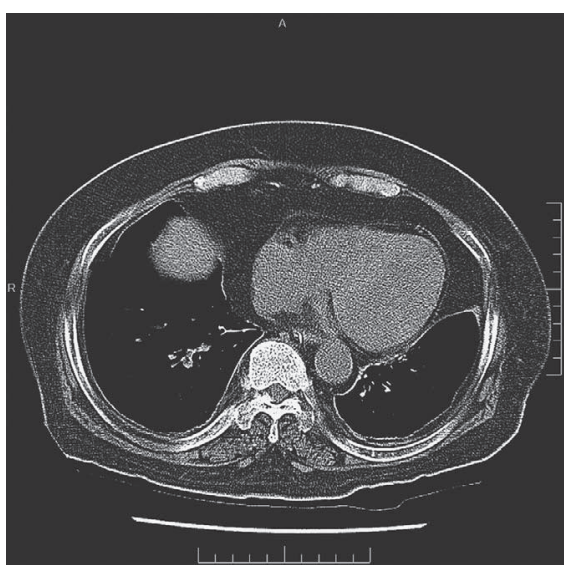

Picture 1.

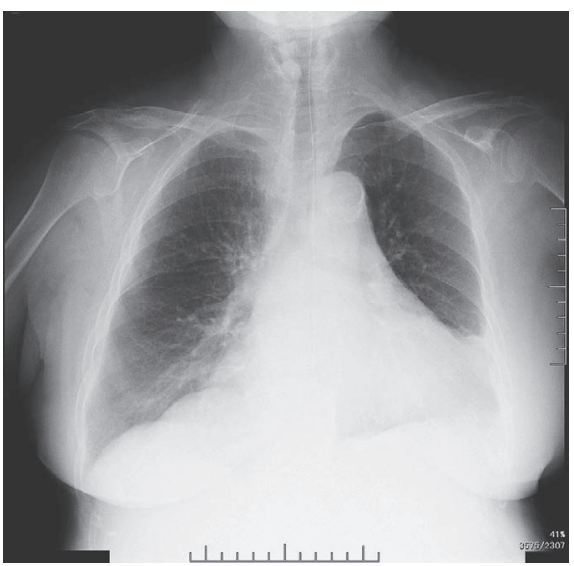

Picture 2.

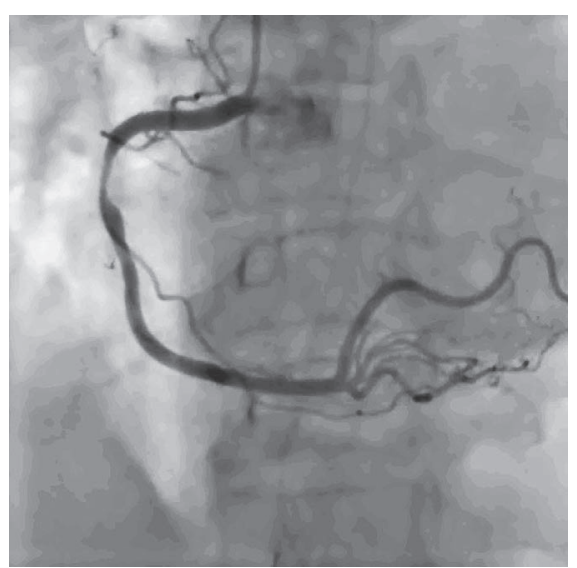

Picture 3.
A 78-year-old woman, diagnosed with Crohn's disease twenty years previously, was admitted to our hospital for the surgical treatment for osteoarthritis of the knee. At preoperative examination, plain radiographs of the chest showed an enlargement of the heart (Picture 1). Remarkable epicardial adipose tissue was seen on the chest computed tomography (CT) (Picture 2). Recently, Pracon et al reported that epicardial adipose tissue is independently related to coronary atherosclerosis (1). In addition, severe stenosis of the right coronary artery was found by coronary angiography (Picture 3). Since she sometimes had an chest pain on effort, and inflammatory bowel disease is associated with an increased incidence of cardiovascular events (2), percutaneous coronary intervention was performed for the severe stenosis.

The authors state that they have no Conflict of Interest (COI).

\section{References}

1. Pracon R, Kruk M, Kepka C, et al. Epicardial adipose tissue radiodensity is independently related to coronary atherosclerosis. A multidetector computed tomography study. Circ J 75: 391-397, 2011.

2. Yarur AJ, Deshpande AR, Pechman DM, Tamariz L, Abreu MT, Sussman DA. Inflammatory bowel disease is associated with an increased incidence of cardiovascular events. Am J Gastroenterol 106: 741-747, 2011.

Department of Cardiology, Fukuoka University School of Medicine, Japan

Received for publication September 14, 2011; Accepted for publication September 16, 2011

Correspondence to Dr. Yusuke Fukuda, zfukusuke@minf.med.fukuoka-u.ac.jp

(C) 2012 The Japanese Society of Internal Medicine Journal Website: http://www.naika.or.jp/imindex.html 